\title{
Efficiency of Cardboard Crowning on the Suppression of Invasive Alien Grasses
}

\author{
Fernando Gonçalves ${ }^{1}$ (1) \\ Izar Aximoff ${ }^{1}$ \\ Alexander Silva de Resende ${ }^{2}$ (D) \\ Guilherme Montandon Chaer ${ }^{2}$
}

\author{
${ }^{1}$ Universidade Federal Rural do Rio de Janeiro (UFRRJ), Instituto de Florestas (IF), Programa de Pós-Graduação em Ciências Ambientais e \\ Florestais (PPGCAF), Seropédica, RJ, Brasil. \\ ${ }^{2}$ Empresa Brasileira de Pesquisa Agropecuária, Seropédica, RJ, Brasil.
}

\begin{abstract}
Invasive exotic grasses are among the biggest obstacles to the success of reforestation projects. The aim of this study was to evaluate the efficiency of the crowning with cardboard in suppressing the grasses Urochloa humidicola and Megathyrsus maximus aiming its use in reforestation areas. A field experiment was installed in a completely randomized design with two treatments consisted of crowning with cardboard and without crowning (control). The crowning with cardboard caused a progressive reduction of the biomass and was effective in causing senescence of both grasses in $80 \%$ or more of the crowning area between 20 and 50 days after the crowning ( $F$ test; $p<0,05$ ). These results demonstrate the effectiveness and potential of using the crowning with cardboard to control alien grass species in reforestation areas. This method brings as an innovation the possibility of placing cardboard directly on the grass after mowing, allowing greater simplicity and lower operating cost.
\end{abstract}

Keywords: grasses suppression, reforestation, weed competition.

\section{INTRODUCTION AND OBJECTIVES}

The main objective of planting natural forests in Brazil is to restore forest ecosystems, previously suppressed, in areas of permanent preservation and legal reserve of rural properties, as determined by the Brazilian Forest Code (Law 12.651, of May 25, 2012). These areas are generally pasture areas, usually dominated by exotic grasses that are difficult to eliminate and replace with a biodiverse and multi-stratified forest vegetation (Dias et al., 2013). Several African grasses brought to Brazil and used as fodder have spread over large areas and alter the evolution of native species by competition for essential resources (water, light, nutrients and space) or allelopathy (Martins et al., 2007; Santos et al., 2019ab). Notorious examples in Brazil include Molasses grass (Melinis minutiflora) in tropical savanna (Hoffmann et al., 2004; Rossi et al., 2014), Palisade signalgrass (Urochloa brizantha) in savanna (Gorgone-Barbosa et al., 2015), Signalgrass
(Urochloa decumbens) in tropical forest/savanna (Silvério et al., 2013) and Guinea grass (Megathyrsus maximus) in tropical forest and grassland (Dias et al., 2013).

Control of fast-growing exotic grass species is one of the main management practices necessary in the initial stages of reforestation in tropical environments, since these grasses can reduce the growth of the trees and impede forest regeneration (Silva, 2012; Resende \& Leles, 2017). Therefore, active control interventions are necessary, usually in the form of mechanical, chemical and/ or bioherbicidal control (Lake \& Minteer, 2018; Benites et al., 2020). While these control methods can be effective, they require follow-up applications, and thus, can be exorbitantly expensive (Resende \& Leles, 2017; Quirion et al., 2018). In Rio de Janeiro state, southeast Brazil, reforestation costs per hectare of Atlantic Forest can exceed U\$ 6.500,00, due to the necessary threeyear maintenance period for planted areas, including 8 to 12 interventions, involving crowning of seedlings and mowing (Leles et al., 2015). These 
operations are frequently neglected due to either difficulty with access or to the high costs involved, often leading to reforestation failure (Toledo et al., 1996; Wittenberg \& Cock, 2001; Monquero et al., 2011; Santos et al., 2019).

In this sense, crowning seedlings with cardboard has been proposed as an efficient and low-cost alternative for controlling weed competition in reforestation areas (Martins et al., 2004; Palhares et al., 2011; Gonçalves et al., 2018; Silva et al., 2018; Benites et al., 2020). Cardboard is expected to inhibit seed germination and also lead to the senescence and death of undesirable existing vegetation, in order to control competition. However, these previous studies have not evaluated the feasibility of placing cardboard directly on the grass, a situation in which the need for crowning with a hoe would be avoided prior to planting or before cardboard crowning after planting. Thus, this study aimed to evaluate the effectiveness of the direct crowning with cardboard in the suppression of Urochloa humidicola and Megathyrsus maximus, two species of forage grasses usually found in reforestation areas in the Atlantic Forest biome.

\section{MATERIAL AND METHODS}

\subsection{Study area and species}

The experiment was conducted in an area of approximately 6 hectares, belonging to Embrapa Agrobiologia, located in Seropédica municipality, Rio de Janeiro state (UTM 23K 635182 E, 7483547 S), meant for reforestation with native species. Two sites were selected based on the presence of different forage invasive grasses (Poaceae) as follows: Site 1: Urochloa humidicola (Rendle) Morrone and Zuloaga (Koronivia grass), and Site 2: Megathyrsus maximus (Jacq.) B.K.Simon and S.W.L.Jacobs (Guinea grass). These species have survival mechanisms that make them very aggressive due to the high production capacity of seeds of high viability and longevity, which can germinate in different types of soil with high or low fertility. These species can still reproduce vegetatively and have a great capacity to regenerate their clumps, once cut. M. maximus, was accidentally introduced to Brazil from slave ships, serving as beds for slaves (Nagano et al., 2011). They are aggressive and resistant species, dispersing easily, significantly interfering with infested crops. Without control, they can replace native species and, with the soil covered, it is very difficult to grow new trees (Silva, 1969; Ammondt \& Litton, 2012; Dias et al., 2016; Mantoani et al., 2016).

The soil of the area is classified as Haplic Planosol (soil fertility analysis of the area: $\mathrm{pH}=5.9$; total carbon $=1 \%$; $\mathrm{Al}=0 \mathrm{cmol}_{c} \cdot \mathrm{dm}^{-3} ; \mathrm{H}+\mathrm{Al}=2.8 \mathrm{cmol}_{c} \cdot \mathrm{dm}^{-3} ; \mathrm{Ca}=2 \mathrm{cmol}_{c}$. $\mathrm{dm}^{-3} ; \mathrm{Mg}=1 \mathrm{cmol} \cdot \mathrm{dm}^{-3} ; \mathrm{K}=91 \mathrm{mg} \mathrm{L}^{-1} ; \mathrm{P}=5.7 \mathrm{mg} \mathrm{L}^{-1}$;
$\mathrm{N}=0.1 \%)$. The soil texture is sandy, with approximately $15 \%$ clay. The relief of the place is slightly wavy, tending to flat in some places, between $24 \mathrm{~m}$ and $38 \mathrm{~m}$ of altitude. The area remained fallow for at least 30 years, having suffered burnings and periodic grazing. There is no record of previous crops in the area. The climate of the region is Aw, characterized by a dry season in winter (especially from June to September) and a humid one in summer. The records of the municipality of Seropédica between January 2009 and December 2013 indicate an annual rainfall of $1,370 \mathrm{~mm}$, with average monthly temperatures ranging from $16{ }^{\circ} \mathrm{C}$ to $36{ }^{\circ} \mathrm{C}$ and an annual average around $24^{\circ} \mathrm{C}$. The annual mean relative air humidity in the same period was $81 \%$ (INMET, 2014). The maximum temperature and amount rainfall during the study months (September 2015 to January 2016) ranged between $37.7^{\circ} \mathrm{C}$ and $40.9^{\circ} \mathrm{C}$ and between $95.2 \mathrm{~mm}$ and $207.2 \mathrm{~mm}$ respectively (https://bdmep.inmet.gov.br/).

\subsection{Design and conduction of experiments}

The grasses at the experimental sites were mowed one week before the experiments were set up. The experiment was set up in a completely randomized design with 5 replications and plots subdivided over time. The treatments consisted of crowning with cardboard (Cardboard) and a control, without crowning (Control). The position of the experimental plots ("crowns") was marked with bamboo stakes, simulating a seedling (Figure 1). The installing of the experiments at each site was in september 2015. In the cardboard treatment, the crowning was performed with B wave kraft cardboard sheets of $50 \times 50 \mathrm{~cm}$ containing a cut from the edge to the center made with a box cutter. The cardboard was placed directly on the grass, without prior weeding.

To fix the cardboard to the soil, 4 staples made from galvanized wire with a $2.77 \mathrm{~mm}$ gauge and $20 \mathrm{~cm}$ in length, folded in a "U" shape, were used. The use of four staples for fixing the four cardboard ends, including a fifth at the place where the stylet cut was performed, improve the cardboard efficiency in containing the grass growth. No chemical treatment was performed on the cardboard used in this study. In the control treatment, no type of intervention was performed after mowing, causing the grass to develop under normal conditions without any type of impediment. In each site, 25 experimental units (crowns) were placed for each treatment.

\subsection{Monitoring of Biomass and Grass Senescence}

Samples of grass biomass in the crown area were carried out in at zero, 35, 75 and 120 days after the installation of the experiment in the field. For sampling, a square mold with an 
area of $0.25 \mathrm{~m}^{2}$ (area equivalent to the area of the cardboard crown) was used. In the control treatments (without crown) the mold was placed on the soil, with bamboo, the marker of each sample unit, in the center. In crowning treatments, the cardboard was removed before placing the mold. In each sample unit, delimited by the mold, all grass (alive or senescent) was collected with the help of pruning shears. The procedure was repeated in five sample units of each treatment per sampling date at each site. The collected material was weighed fresh and subsequently dried in a forced circulation oven at $65^{\circ} \mathrm{C}$ for 72 hours and weighed again to obtain the dry grass mass. The results were expressed in vegetation biomass per $\mathrm{m} 2$, being calculated by dividing the dry weight

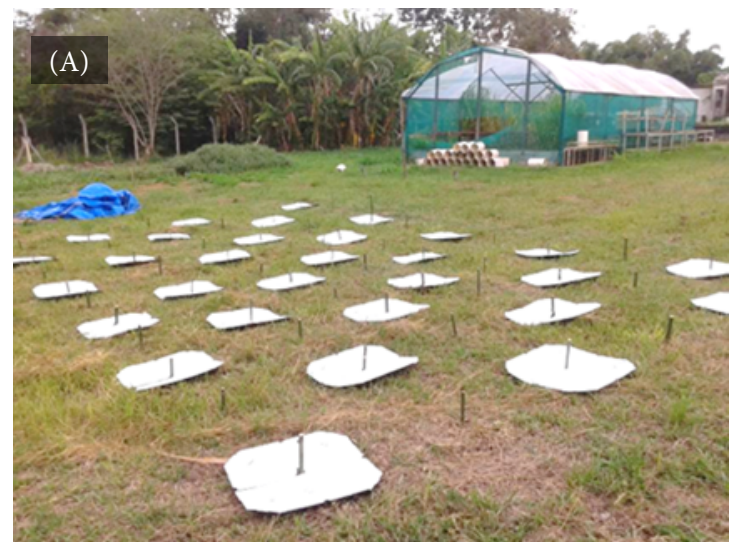

of each sampling point by 0.25 . The senescence level of the grass crowned with cardboard was assessed visually and classified according to the following scale: (1) green grass, with no sign of senescence in more than $80 \%$ of the crown area, (2) yellowish or partially desiccated grass in more than $80 \%$ of the crown area; (3) grass dried out or in the process of decomposition in more than $80 \%$ of the crown area (Figure 1).

\subsection{Data analysis}

The data obtained at each site were analyzed independently. The dry biomass data were analyzed on each collection date using the test at a $5 \%$ significance level to compare the two treatments.

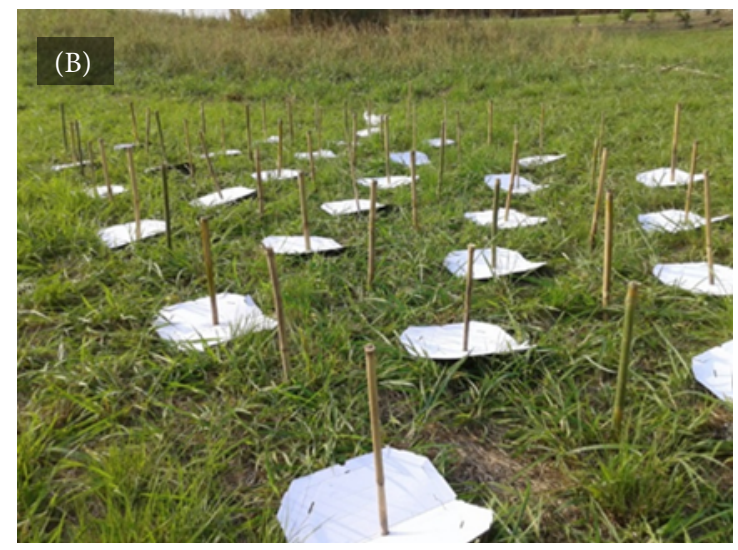

Figure 1. General views of the experimental sites with Urochloa humidicola (A) and Megathyrsus maximus (B). Bamboo poles were used to simulate seedlings in the field.

\section{RESULTS AND DISCUSSION}

The biomass of both grasses studied showed a significantly lower value under cardboard, compared to the control, throughout the monitoring period ( $p<0,05 ;$ Figure 2$)$. At 120 days after the installation of the study, the biomass of $U$. humidicola under the cardboard was approximately $100 \mathrm{~g} / \mathrm{m}^{2}$, approximately $33 \%$ of that found at the time of installing the cardboard, while in the control the biomass of the grass reached $425 \mathrm{~g} / \mathrm{m}^{2}$. For $M$. maximus, this effect was even greater with the biomass under the cardboard being reduced to approximately $50 \mathrm{~g} / \mathrm{m}^{2}$ about $20 \%$ in relation to the moment of the cardboard placement, while the control reached $700 \mathrm{~g} / \mathrm{m}^{2}$ of biomass (Figure 2). The senescence process of invasive grasses under the cardboard were already at level 2 since the first evaluation ( 35 days after crowning), and reached level 3 in the last evaluation (120 days after crowning), showing itself to be desiccated or undergoing decomposition in more than $80 \%$ of the crown area (Figure 3 ).

Lower light availability for the soil unfavors the spread, germination an sprouting of invasive grasses because they are highly intolerant to shading (Pereira et al., 2012). Under intense shading, when virtually all light is blocked, the photosynthetic mechanism is compromised, leading to senescence and death of the plant. Therefore, the sunlight blocked by the cardboard, once placed directly over the weeds, caused the loss of biomass and the senescence of both grass species as we identified here.

Several previous studies have shown the efficiency of cardboard crowning to control exotic grasses in reforestation projects. Silva et al. (2018) showed, through photo documentation, that cardboard was effective at controlling Urochloa humidicola growth up to a year after its placement on the ground. Gonçalves et al. (2018) succeded in controlling Andropogon bicornis with cardboard crowning in a reforestation in Seropédica, RJ, while Benites et al. (2020) also succeded in controlling Urochloa decumbens (Stapf) R.D.Webster and Paspalum notatum Flüggé (Poaceae) using the same method in the Cerrado of the Mato Grosso do Sul state. However, in all those studies the weeds were crowned with hoe before placing the cardboard, which involves additional labor costs. 


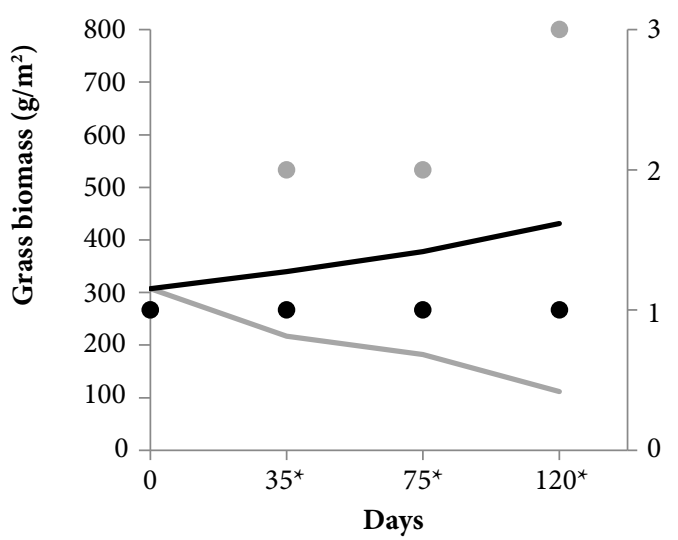

B

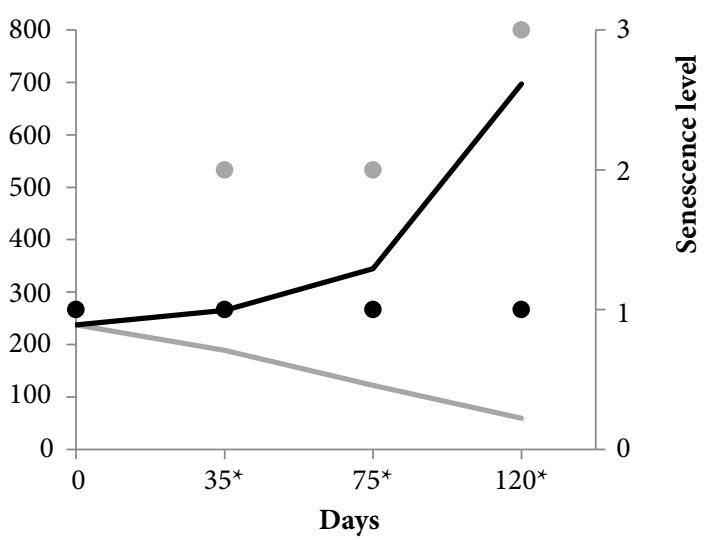

Figure 2. Amount of biomass (lines) and senescence level (dots) of Urochloa humidicola (A) and Megathyrsus maximus (B). Gray dots and lines refer to the cardboard treatment while black dots and lines to the control.. Asterisk after each sampling time means that the treatments differed by the $\mathrm{t}$ test $(\mathrm{p}<0.05)$.
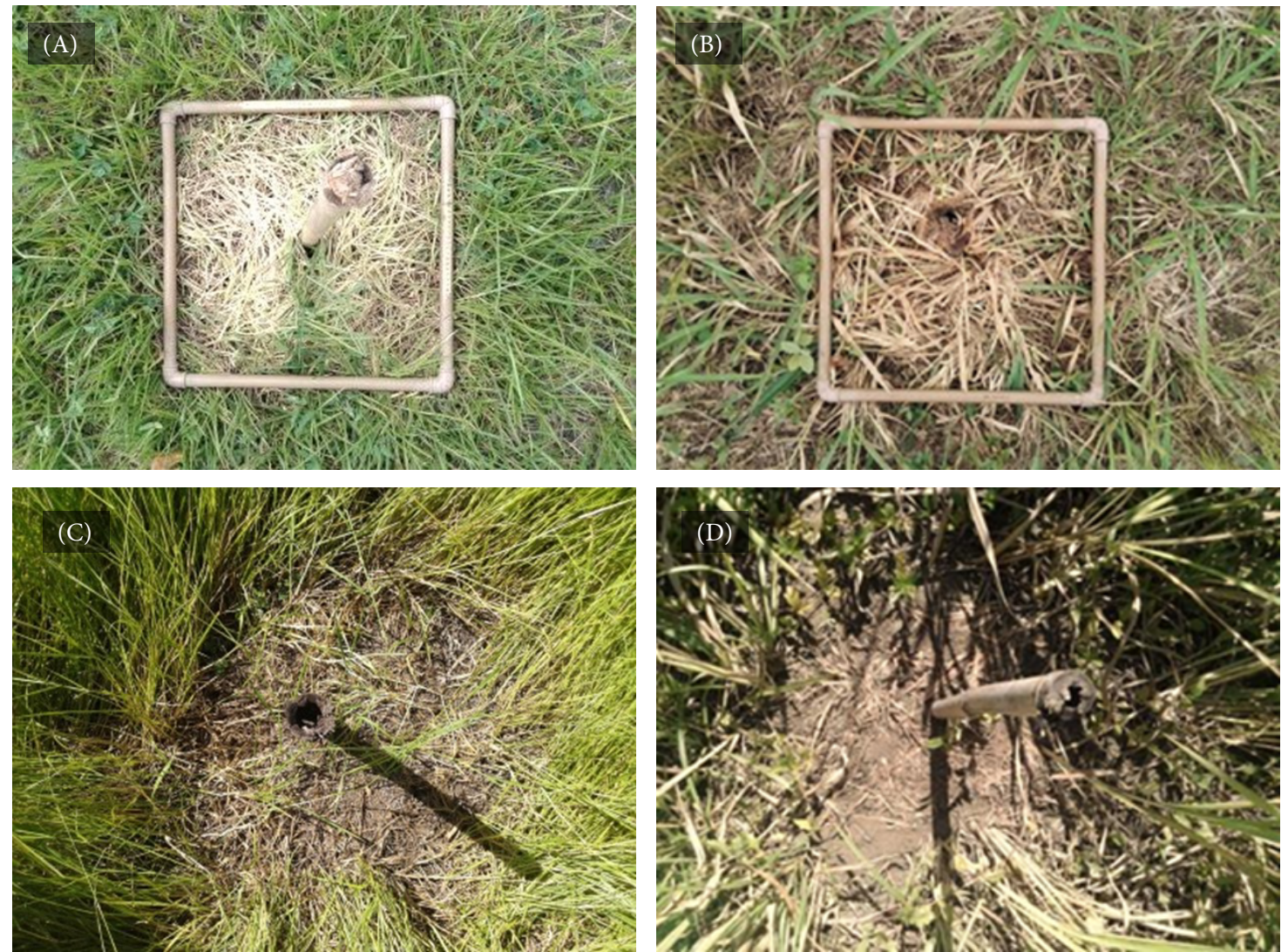

Figure 3. Senescence levels 2 (A) and 3 (C) for U. humidicola and senescence levels 2 (B) and 3 (D) for M. maximus as a result of the cardboard crowning. Photos A and B were taken 35 days after crowning, and photos $\mathrm{C}$ and D 120 days after crowning.

The importance of controlling grasses in reforestation projects aims to obtain greater growth and survival gains for tree species (Ammondt \& Litton, 2012; Dias et al., 2016; Mantoani \& Torezan, 2016; Santos et al., 2019). Gonçalves et al.
(2018) demonstrated that manual crowning of seedlings can be replaced by crowning with cardboard without hindering growth and with the benefit of reducing seedling mortality. In another study, the survival rate and growth of seedlings of 
a Cerrado native tree species (Dipteryx alata Vog.) did not differ between crowning with cardboard or hoe, but cardboard treatment resulted in better weed control (Benites et al., 2020).

Cardboard can be also effective in controlling soil temperature affecting plant growth over time (Benites et al., 2020), since many nutrients essential for its development are only released at certain temperature ranges (Gasparin et al., 2005). A strong effect of cardboard mulching on soil temperature was noted on days with high air temperatures, which proved up to $15^{\circ} \mathrm{C}$ lower in the 0 to $10 \mathrm{~cm}$ deep layer compared to bare soil (hoe crowning) areas (Silva et al., 2018). This cardboard effect may have consequences on seedlings development under field conditions, given that it improves the soil environment for rooting due, for instance, to less water loss and more favorable conditions for biological activity.

One of the greatest benefits of crowning seedlings with cardboard can be related to the lower cost of operation compared to traditional manual crowning, although the quality of the cardboard and the volume of rainfall in the area can increase these costs (Dias et al., 2019). In a study carried out in a riparian forest in the Atlantic Forest biome, the use of cardboard cut the working time in half (Palhares, 2011). Other studies have also shown significant reductions in operating costs with the use of cardboard for crowning. Benites et al. (2020) showed costs $20 \%$ lower for crowning with cardboard compared to traditional crowning with hoe. The material and labor costs used for crowning with cardboard were $43 \%$ lower than the costs of manual crowning with a hoe over a year (Gonçalves et al., 2017). The cost of cardboard can be further reduced if the purchase is made of reused material from packaging of market products or even pizza boxes.

Our results showed that the crowning with cardboard can be carried out directly on the grasses, making it possible to eliminate the manual crowning operation prior to placing the cardboard. According to Gonçalves et al., (2018), the cost for hoe crowning before placing the cardboard in the field represent about $20 \%$ of the total budget for the crowning operation with cardboard in the first year. Therefore, the findings of this study can further enhance the attractiveness to the adoption of the cardboard crowning technique, considering the crowning operation a large part of the reforestation budget.

The development of low-cost techniques for reforestation actions subsidizes the implementation of the National Plan for the Recovery of Native Vegetation in Brazil, facilitating the expansion of its scale. This plan aims to present strategies to motivate and implement reforestation in the next 20 years (Brazil 2017). The benefit of cardboard may be more related to the reduction of crowning maintenance frequency to avoid competition with invasive alien grasses and, owing to its conspicuity, facilitating the recognition of seedlings during maintenance actions and also, being a cheap and environmentally viable technique owing to its biodegradability.

In this study, the use of cardboard, placed directly over the weeds, was effective in suppressing the growth and cause the senescence of two invasive grasses (U. humidicola and $M$. maximus). This fact was verified by the loss of biomass and / or by the visual analysis that showed loss of vigor, yellowing and death of the grasses over the evaluation period. It is imperative to use four staples (or any similar apparatus) for fixing the cardboard when the crowning is performed directly on the newly mowed grass. The results of the present study reinforce the potential of using cardboard to control invasive grasses during forest reforestation initiatives, and bring as an innovation the possibility of placing cardboard directly on grasses after mowing, allowing greater simplicity and lower cost of operation.

\section{ACKNOWLEDGEMENTS}

This study was financed in part by the Coordenação de Aperfeiçoamento de Pessoal de Nível Superior - Brasil (CAPES) - Finance Code 001.

\section{SUBMISSION STATUS}

Received: 18 Mar. 2021

Accepted: 29 Apr. 2021

Associate editor: Rodrigo Studart Corrêa (1)

\section{CORRESPONDENCE TO} Izar Aximoff

Universidade Federal Rural do Rio de Janeiro (UFRRJ), Instituto de Florestas (IF), Programa de Pós-Graduação em Ciências Ambientais e Florestais (PPGCAF), BR 465 Km 07, CEP: 23.890-000, Seropédica, RJ, Brasil

e-mail: izar.aximoff@gmail.com

\section{REFERENCES}

Ammondt SA, Litton CM. Competition between native Hawaiian plants and the invasive grass Megathyrsus maximus: implications of functional diversity for ecological restoration. Restoration Ecology 2012; 20: 638-646.

Benites RMA, Guerra A, Reis LK, Dos Santos Ferreira BH, Borges FLG, Ferreira IJK, Garcia LC. Nucleário, cardboard, or manual crowning: which maintenance technique is most cost-effective in tree seedling survival establishment? Journal of Environmental Management 2020; 270: 110900.

Brazil. Decree 8,972/2017. Institui a Política Nacional de Recuperação da Vegetação Nativa. 2017. http://www.planalto.gov.b r/ccivil_03/_ ato2015 2018/2017/decreto/D8972.htm

Dias J, Mantoani MC, Baptista R, Fonte Mama, Holdefer D, Torezan JMD. Invasive Alien Plants In Brazil: A Nonrestrictive Revision Of Academic Works. Natureza \& Conservação 2013, v. 11, p. 31-35. 
Dias J, Surian T, Mantoani MC, Pereira LCDSM, Torezan JMD. Crescimento de Megathyrsus maximus (capim-colonião) e duas espécies nativas arbóreas em diferentes condições ambientais. Floresta 2016; 46: 325-334.

Dias MMM, da Silva Santana JE, dos Santos Leles PS, de Resende AS, Ribeiro JG. Coroamento com papelão para controle de braquiária na formação de povoamento para restauração florestal. Pesquisa Florestal Brasileira 2019; 39: 1-6.

Gasparin E, Ricieri RP, Silva SL, Dallacort R, Ganoatto R. Temperatura no perfil do solo utilizando duas densidades de cobertura e solo nu. Acta Scientiarum. Agronomy 2005; 27: 107-115.

Gonçalves FLA, Resende AS, Lima ISS, Chaer GM. Manual crowning versus cardboard in forest restoration: costs and effect on seedling development. Planta Daninha 2018; 36: e018167569. https://doi.org/10.1590/s0100- 83582018360100107.

Gonçalves, F. L. A. Efeito do coroamento com papelão na supressão de gramíneas e no crescimento de espécies arbóreas. Dissertação (Mestrado). Universidade Federal Rural do Rio de Janeiro, Rio de Janeiro, Brasil. 2016.

Gorgone-Barbosa E, Pivello VR, Bautista S, Zupo T, Rissi MN, Fidelis A. How can an invasive grass affect fire behavior in a tropical savanna? A Community and individual plant level approach. Biological Invasions 2015; 17: 423-431.

Guerra A, Reis LK, Borges FLG, Ojeda PTA, Pineda DAM, Miranda $\mathrm{CO}, \ldots$ \& Laurance SG. Ecological restoration in Brazilian biomes: Identifying advances and gaps. Forest Ecology and Management 2020; 458, 117802 .

Hoffmann WA, Lucatelli VM, Silva FJ, Azeuedo IN, Marinho MDS, Albuquerque AMS, Lopes ADO, Moreira SP. Impact of the invasive alien grass Melinis minutiflora at the savanna-forest ecotone in the Brazilian Cerrado. Diversity and Distributions 2004; 10: 99-103.

Lake EC, Minteer CR. A review of the integration of classical biological control with other techniques to manage invasive weeds in natural areas and rangelands. BioControl 2018; 63: 71-86.

Mantoani MC, Andrade GR, Cavalheiro AL, Torezan JMD. Efeitos da invasão por Panicum maximum Jacq. e do seu controle manual sobre a regeneração de plantas lenhosas no sub-bosque de um reflorestamento. Semina: Ciências Biológicas e da Saúde 2012; 33: 97-110.

Mantoani MC, Torezan JMD. Regeneration response of Brazilian Atlantic Forest woody species to four years of Megathyrsus maximus removal. Forest Ecology and Management 2016; 359: 141-146.

Martins EG, Neves EJM, Santos AF, Ferreira CA. Papelão tratado: alternativa para controle de plantas daninhas em plantios de pupunheira (Bactris gasipaes Kunth). Colombo: EMBRAPA Florestas 2004; 4 p. Comunicado Técnico.

Martins CR, Hay JD, Valls JFM, Leite LL, Henriques RPB. Levantamento das gramíneas exóticas do Parque Nacional de Brasília, Distrito Federal, Brasil. Natureza \& Conservação 2007; 5: 23-30.

Monquero PA, Penha AS, Orzari I, Hirata ACS. Seletividade de herbicidas em mudas das espécies nativas - Acacia polyphylla, Enterolobium contortisiliquum (Fabaceae), Ceiba speciosa e Luehea divaricata (Malvaceae). Planta Daninha 2011; 29: 159-168. http://dx.doi.org/10.1590/S0100- 83582011000100018

Nagano NR, Zanet C, Tritan CS, Santos DH. Effect of nitrogen fertilization and cutting height on Tanzania guinea grass. Scientia Agraria Paranaensis 2011; 10: 100-112.
Nascimento DF. Avaliação do crescimento inicial, custos de implantação e de manutenção de reflorestamento com espécies nativas em diferentes espaçamentos. [Monografia] Seropédica: Universidade Federal Rural do Rio de Janeiro; 2007.

Palhares AO. Contribuição para recuperação de matas ciliares: uso de papelão em substituição à capina de coroamento, no plantio e condução de mudas florestais. São Paulo: IPT; 2011.

Pereira FCM, Yamauti MS, Alves PLCA. Interação entre manejo de plantas daninhas e adubação de cobertura no crescimento inicial de Eucalyptus grandis x E. urophylla. Revista Árvore 2012; 36: 941-949. http://dx.doi.org/10.1590/S0100-67622012000500016

Quirion B, Simek Z, Da'Valos A, Blossey B. Management of invasive Phragmites australis in the Adirondacks: a cautionary tale about prospects of eradication. Biological Invasions 2018; 20: 59-73.

Resende AS, Leles PSS. Controle de plantas daninhas em restauração florestal. Embrapa, Brasilia, Brazil. 2017.

Rossi RD, Martins CR, Viana PL, Rodrigues EL, Figueira JEC. Impact of invasion by molasses grass (Melinis minutiflora P. Beauv.) on native species and on fires in areas of campo-cerrado in Brazil. Acta Botanica Brasilica 2014; 28: 631-637.

Santos TA, Resende AS, Silva FF, Moraes LFD, Chaer GM. Growth of tree species in coexistence with palisade grass Urochloa brizantha (Hochst. Ex A. Rich.) Stapf CV. Marandu. Planta Daninha 2019a; 37: e019178812.

Santos TA, De Resende AS, Da Silva FF, Machado AFL, Chaer GM. Weed interference factors that affect the growth on an Atlantic Forest tree species. Bioscience Journal 2019b, 35: 485-494.

Silva FFD, Resende ASD, Santos TAD, Chaer GM. Use of cardboard disks for crowning seedlings in reforestation. Floresta e Ambiente 2018; 25.

Silva SAF. Contribuição ao estudo do "capim-colonião" (Panicum maximum Jacq. var. maximum). II - Considerações sobre sua dispersão e seu controle. Vellozia 1969; 7: 3-21.

Silva FF. Avaliação de tratamentos químicos para aumentar a durabilidade de discos de papelão para uso no coroamento de mudas em reflorestamentos [Monografia]. Seropédica: Universidade Federal Rural do Rio de Janeiro; 2014.

Silveira FA, Arruda AJ, Bond W, Durigan G, Fidelis A, Kirkman $\mathrm{K}, \ldots$ \& Siebert, SJ. Myth-busting tropical grassy biome restoration. Restoration Ecology, 2020; 28(5): 1067-1073.

Silvério DV, Brando PM, Balch JK, Putz FE, Nepstad DC, OliveiraSantos C, Bustamante MM. Testing the Amazon savannization hypothesis: fire effects on invasion of a neotropical forest by native cerrado and exotic pasture grasses. Philosophical Transactions of the Royal Society B: Biological Sciences 2013; 368: 20120427.

Sutton GF, Canavan K, Day MD, Den Breeyen A, Goolsby JA, Cristofaro M, Paterson ID. Grasses as suitable targets for classical weed biological control. BioControl 2019; 1-18.

Toledo REB, Alves P, Valle C, Alvarenga SF. Comparação dos custos de quatro métodos de manejo de Brachiaria decumbens Stapf em área de implantação de Eucalyptus grandis W. Hill ex Maiden. Revista Árvore 1996; 20: 319-330.

Wittenberg R, Cook MJW. Invasive alien species: a toolkit of best prevention and management practices. CAB International, Wallingford. 2001. 